\title{
Modelling of a vacuum consolidation project in Vietnam
}

\author{
Nguyen Trong Nghia ${ }^{1 *}$ \\ ${ }^{1}$ Ho Chi Minh City Open University, Vietnam \\ *Corresponding author: nghia.nt@ou.edu.vn
}

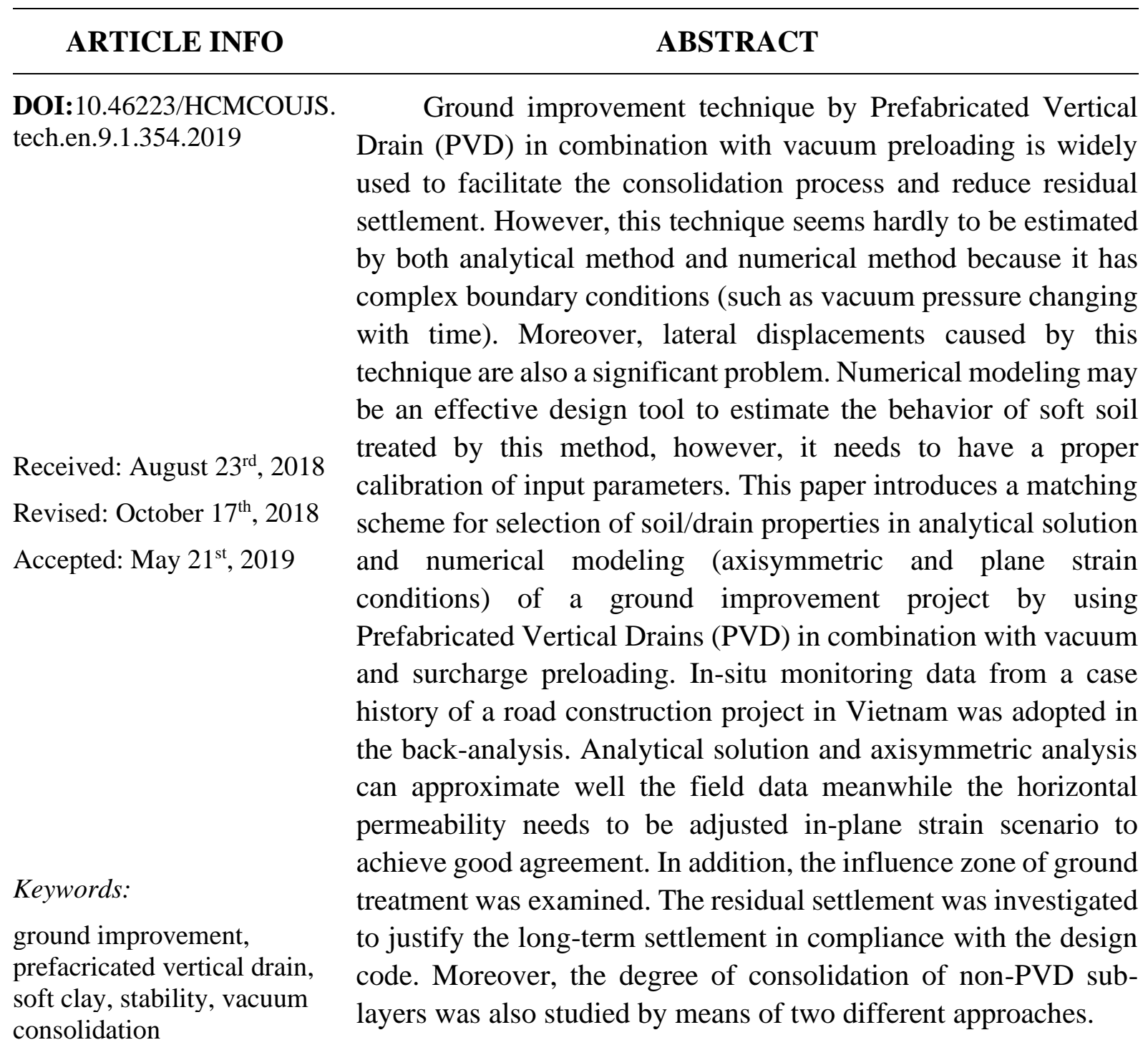

\section{Introduction}

\subsection{Site}

Due to the rapid development of industrial zones in Vietnam, infrastructures such as roads need to be built faster. Therefore, it requires a faster soft soil treatment method rather than traditional methods such as a vertical sand drain or vertical Prefabricated Drain (PVD) with surcharge preloading method. Vacuum consolidation for vertical prefabricated drains in combination with surcharge preloading was proved to be the effective method because of the 
lower embankment surcharge height and shorter construction time than the conventional PVD preloading method (Artidteang, Bergado, Saowapakpiboon, Teerachaikulpanich, \& Kumar, 2011; Bergado, Chai, Miura, \& Balasubramaniam, 1998; Chai, Carter, \& Bergado, 2013b; Chai, Ong, Carter, \& Bergado, 2013a; Chu, Yan, \& Yang, 2000; Geng, Indraratna, \& Rujikiatkamjorn, 2012; Indraratna, Rujikiatkamjorn, \& Sathananthan, 2005; Indraratna, Rujikiatkamjorn, Ameratunga, \& Boyle, 2011; Indraratna, Rujikiatkamjorn, Balasubramaniam, \& McIntosh, 2012; Kelly \& Wong, 2009; Lam, Bergado, \& Hino, 2015; Rujikiatkamjorn \& Indraratna, 2007, 2009, 2013; Yan \& Chu, 2005; Voottipruex, Bergado, Lam, \& Hino, 2014).

Bachiem road project (2017-2018) treated by the PVD vacuum consolidation technique locates in the south of Vietnam. It is 20 kilometers from Ho Chi Minh City as shown in Figure 1. This area is in the Saigon - Dong Nai River Delta (SDRD). The average thickness of the soft clay in this area is more than 20 meters. This soft clay, with low shear strength and high compressibility, may induce large settlement and stability problems for construction (Long, Bergado, Nguyen, \& Balasubramaniam, 2013).

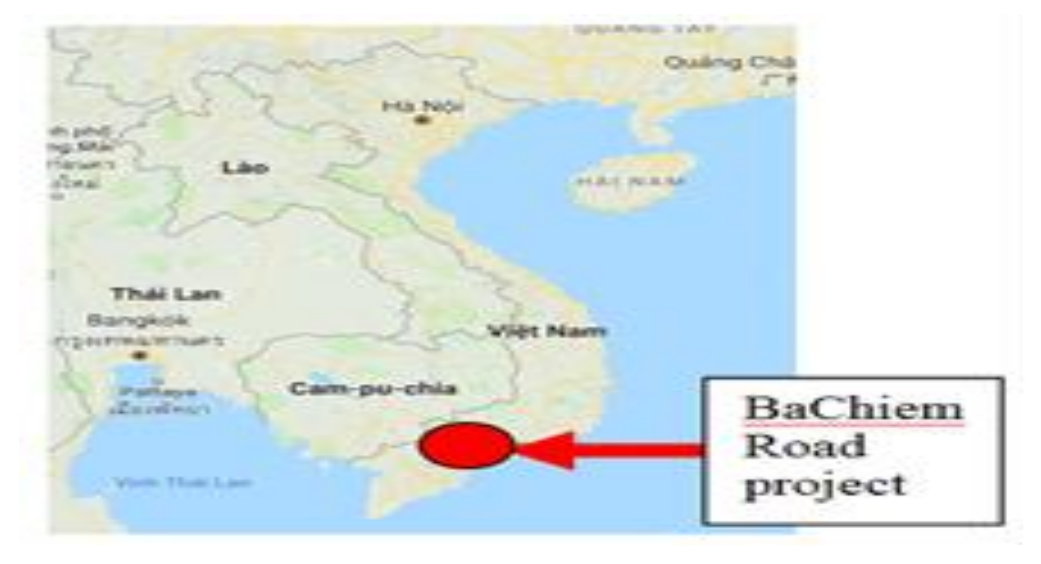

Figure 1. The project location

The Bachiem road project was $2.2 \mathrm{~km}$ long from the Bachiem bridge to Hiep Phuoc Industrial Zone. Figure 2 shows the overall layout of this project. The right-hand side of this project is the Sai Gon river and there are still a number of rice fields and agricultural lands surrounding the project indicating that subs soil is very soft.

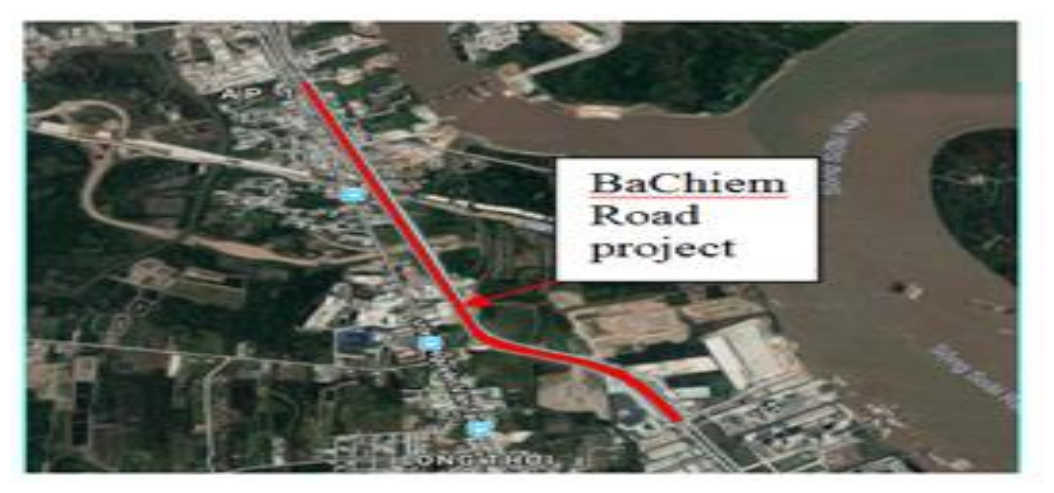

Figure 2. Project's overall layout 
Figure 3 shows a typical section in this project in which numerous monitoring instrumentations were installed to examine soft ground treatment quality and possible damages to nearby houses. A selected section for the numerical model is the section with the PVD's length of $15.5 \mathrm{~m}$ as highlighted in Figure 3. The PVD's length of this section was limited due to the restriction of mandrel height under high electrical voltage lines. This section may cause differential settlements and damages to the future road. Thus, extensive monitoring measurements and ground investigations were carried out. Figure 4 illustrates the analytical section after construction.

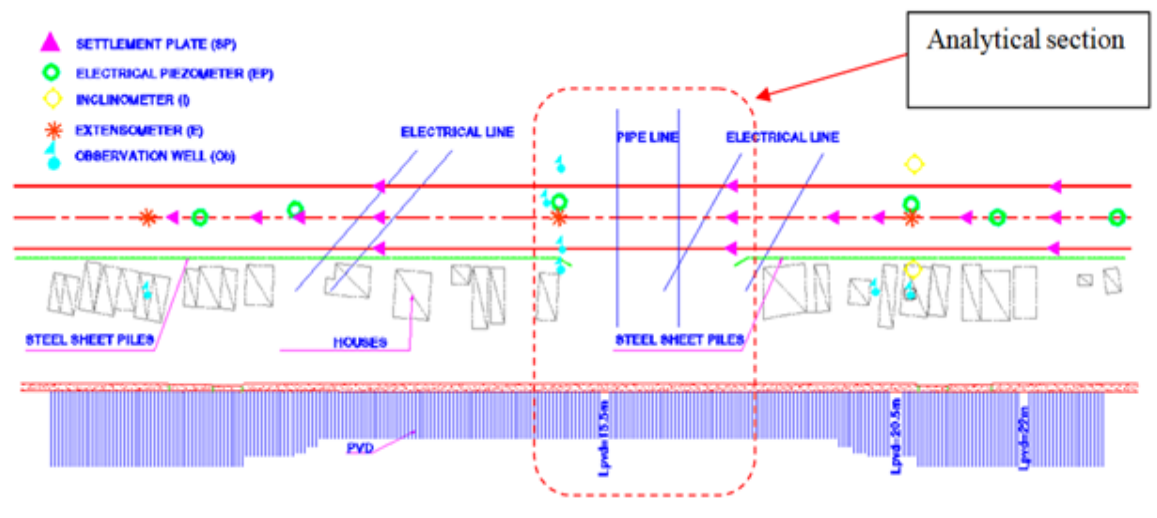

Figure 3. Layout of analytical section

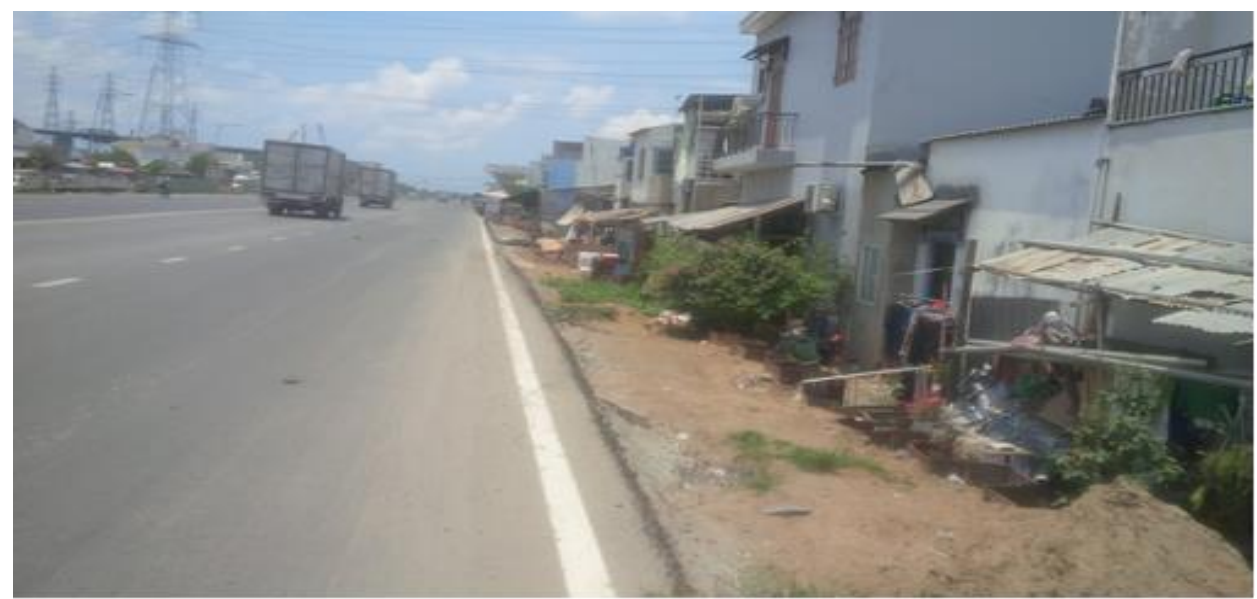

Figure 4. The analytical section after construction

\subsection{Soil profile}

The soil profile of the analysis section consists of 4 sub-soil layers:

- Top crush (0m to $1 \mathrm{~m})$ : the surface soil includes: a thin layer with organic clay, bluegrey, yellow-grey, yellow-brown. This layer is mainly used: for filling the banks, embankments, floor tiling, and rice fields;

- Layer 1a (1m to $23 \mathrm{~m})$ : A very soft clay with some organic matter and thin sand layers with an average water content of $84.5 \%$, plastic limit (PL) of $37.5 \%$, liquid limit (LL) of $91.3 \%$ unit weight of $14.8 \mathrm{kN} / \mathrm{m}^{3}$ and SPT $\mathrm{N}$ values from 0 to 1 ; 
- Layer $1 \mathrm{~b}$ ( $23 \mathrm{~m}$ to $26 \mathrm{~m})$ : A soft clay with some organic matters and thin sand layer with an average water content of $78.1 \%$, PL of $36.6 \%$, LL of $89.1 \%$, unit weight of $1.50 \mathrm{kN} / \mathrm{m}^{3}$, and SPT-N values from 2 to 6 ;

- Layer 2 (26m to $29 \mathrm{~m}$ ) silty or silty sand which is loose to medium dense with SPT$\mathrm{N}$ values from $8-25$.

Layer 1a is very soft to soft clay. Without ground treatment, the road construction would be affected due to the post-settlement. Mechanical properties of layer 1a are: $C R$ (compression ratio $)=0.35, R R($ recompression ratio $)=0.042, O C R($ over consolidation ratio $)=1$ to 2 which decreases with depth and $c v$ (coefficient of vertical consolidation) $=2 \mathrm{~m}^{2} /$ year (for NC stage) as illustrated Figure 5.

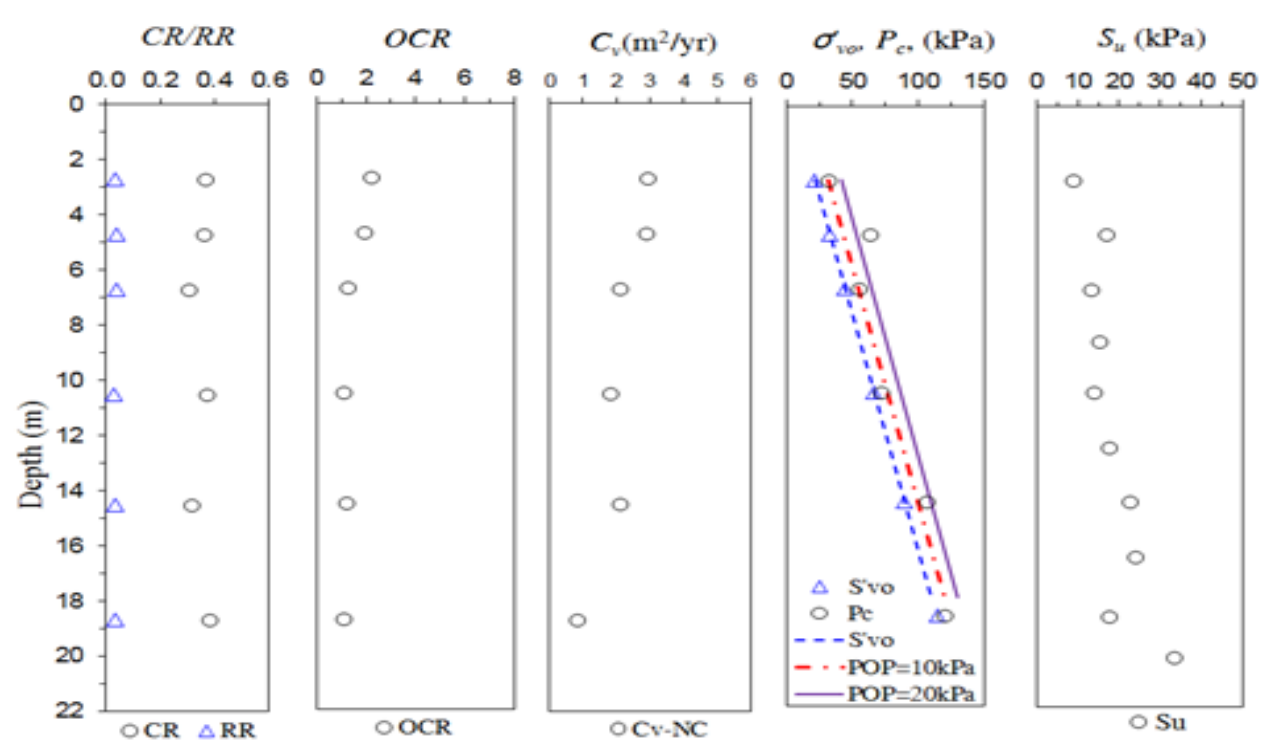

Figure 5. Soil mechanical parameters of layer 1a

The permeability value of layer $1 \mathrm{a}$ is a crucial factor for numerical analyses. In fact, the permeabilities change with pressure and void ratio as shown in Figure 6 and Figure 7. These figures were derived from odometer tests at different depths from the analytical section. The input permeability value for numerical modeling was simplified as a constant value. Therefore, the lab permeability of $k_{v}=1 \times 10^{-5}$ (m/day) is used as a vertical permeability.

For most natural deposits, the horizontal permeability $k_{h}$ is greater than that in the vertical direction, and the ratio $\left(k_{h} / k_{v}\right)$ varies from 1 to 15 (Jamiolkowski, Lancellotta, \& Wolski, 1983). The horizontal permeability, therefore, was assumed as $k_{h}=2 k_{v}=2 \times 10^{-5}$ (m/day). The initial void ratio was simplified as a constant input value $e_{o}=2$ for layer $1 \mathrm{a}$ as shown in Figure 7. 


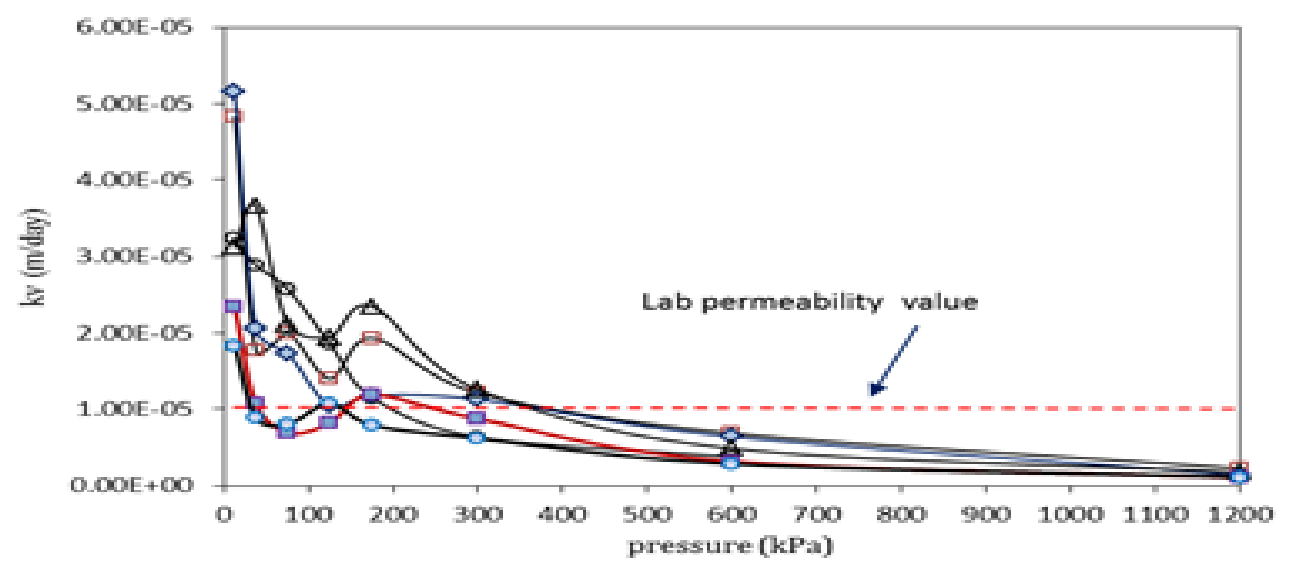

Figure 6. Permeability with pressure changes

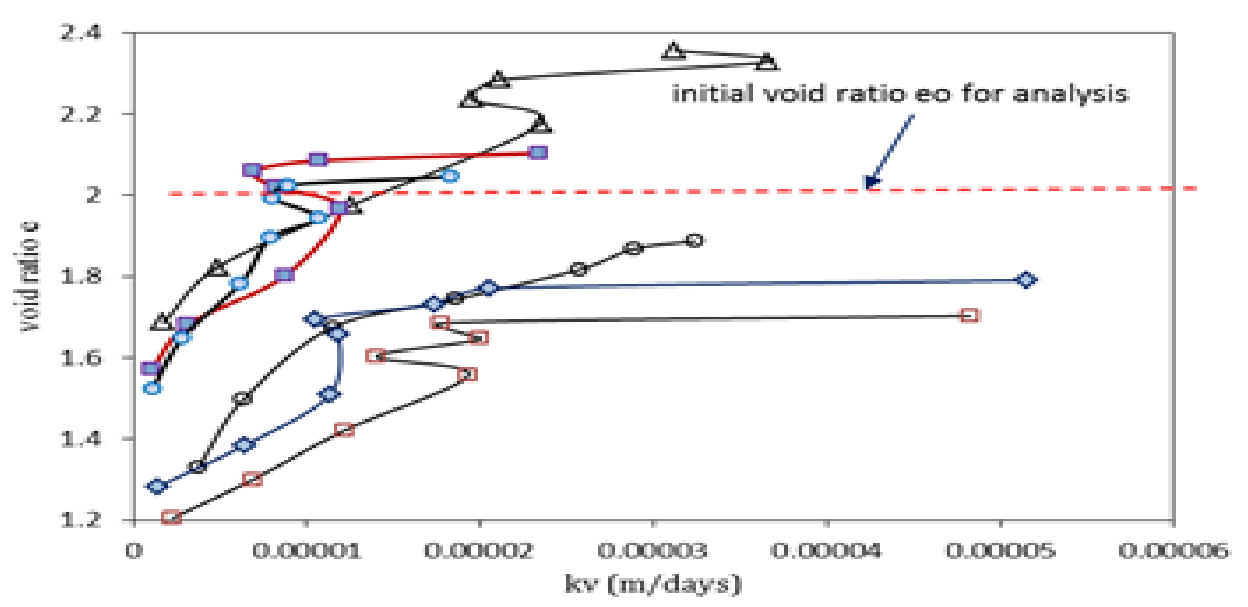

Figure 7. Permeability with void ratio changes

\subsection{PVD properties}

PVDs were installed in a triangle pattern with the spacing of $S=1(\mathrm{~m})$. Thus, the equivalent influential diameter is $D_{e}=1.05 S=1.05(\mathrm{~m})$ (Barron, 1948). The PVDs can be simplified into a circular shape with an equivalent drain's dimension of $d_{w}=\frac{2(a+b)}{\pi}=0.066$ (m) (Rixner et al., 1986). The mandrel dimension was $0.06 \mathrm{~m} \times 0.12 \mathrm{~m}(w \times l)$. Thus, the equivalent mandrel dimension in circular shape was $d_{m}=2 \sqrt{\frac{w l}{\pi}}=0.096(\mathrm{~m})$. Moreover, the diameter of the smear zone is $d_{s}=\frac{(5 \div 6)}{2} d_{m}=0.24 \div 0.29(\mathrm{~m})$ (Rixner et al., 1986). The value of $d_{s}=0.25$ (m) was adopted in this study. Plus, well resistant with very high permeability of the drain $k_{w}=100$ (m/day) was not considered in this model.

\section{Methodology}

A matching scheme is proposed in order to derive the proper properties of soil/drain used in the design stage. It can be done by following 3 steps: 
1- Generating consolidation problem of PVD by the analytical solution (Han, 2015) with initial soil/drain properties. It is noted that the analytical solution by Hansbo (1981) modified by Han (2015) is used for the PVD design of the surcharge preloading technique. It may also be appropriately applied for time-dependent loading and vacuum consolidation technique;

2- Simulating this consolidation problem in a single unit cell under the axisymmetric condition with similar initial soil/drain properties. The permeability ratio of undisturbed clay to smear clay $\left(k_{h} / k_{s}\right)$ is calibrated by the settlement of the numerical model, the analytical solution, and the actual site data. The appropriate soil/drain properties will be adopted in the subsequent 2D numerical model;

3- Modeling complete consolidation case under plane strain (2D) condition. It is to verify both vertical and horizontal displacements with field data.

\section{Results and discussion}

\subsection{Generating analytical solution}

A simplified method by Han (2015) was employed to account for the loading steps. This method converted the earlier degree of consolidation at the time $t_{i}$ and pressure $p_{i}$ to the degree of consolidation $U_{j}$ under new pressure $p_{j}$ with an equivalent time $t_{j}=t_{i}+\Delta t$ in which $\Delta t$ is an additional time calculated using the total time. Further, vacuum pressures are approximately considered as a loading which can be added with the surcharge loading. Initial soil properties taken from Figure 5 are summarized in Table 1. In addition, the horizontal consolidation coefficient $\left(c_{h}\right)$ was assumed to be double the vertical value. In other words, the $c_{h}$ value of 4 $\mathrm{m}^{2} /$ year is adopted. It is noted that the layer top-crush and silty sand layer (layer 2) were neglected in this analytical solution due to their low deformation.

Moreover, the actual loading sequence of the analytical section presented in Figure 8 was carried out with two-step loadings. It was simplified as a single-ramp loading. In addition, vacuum pumps gained the maximum vacuum pressure of $-60 \mathrm{kPa}$ for only 5 days.

Figure 9 demonstrates a comparison of surface settlements by the analytical solution and the field data with the permeability ratio of $k_{h} / k_{s}=3$. The analytical results are in good agreement with the field measurements. Therefore, the initial soil properties and the permeability ratio $k_{h} / k_{s}=3$ are then applied for axisymmetric numerical modeling of the subsequent step.

\section{Table 1}

Initial soil properties for the analytical model

\begin{tabular}{ccccc}
\hline Layer & Depth $(\mathbf{m})$ & RC & RR & $p_{c}(\mathbf{k P a})$ \\
\hline 1a +PVD & $1-3$ & 0.35 & 0.042 & 31.6 \\
1a+PVD & $3-7$ & 0.35 & 0.042 & 49 \\
1a+PVD & $7-11$ & 0.35 & 0.042 & 72.7 \\
1a+PVD & $11-15$ & 0.35 & 0.042 & 95.4
\end{tabular}




\begin{tabular}{ccccc}
\hline Layer & Depth $(\mathbf{m})$ & $\mathbf{R C}$ & $\mathbf{R R}$ & $p_{c}(\mathbf{k P a})$ \\
\hline 1a & $15-19$ & 0.35 & 0.042 & 118.6 \\
1a & $19-23$ & 0.35 & 0.042 & 141.8 \\
1b & $23-26$ & 0.23 & 0.023 & 156.3 \\
\hline
\end{tabular}

Source: The researcher's data analysis

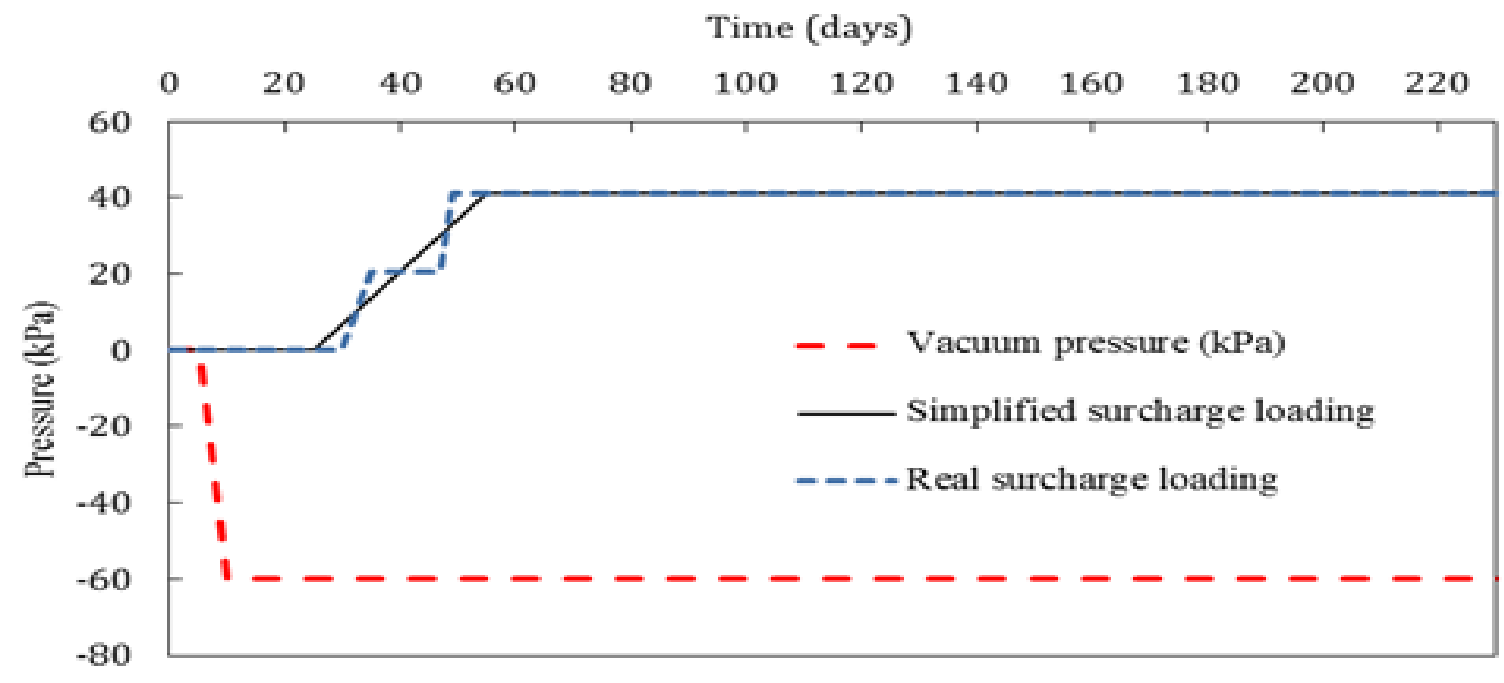

Figure 8. Loading sequence

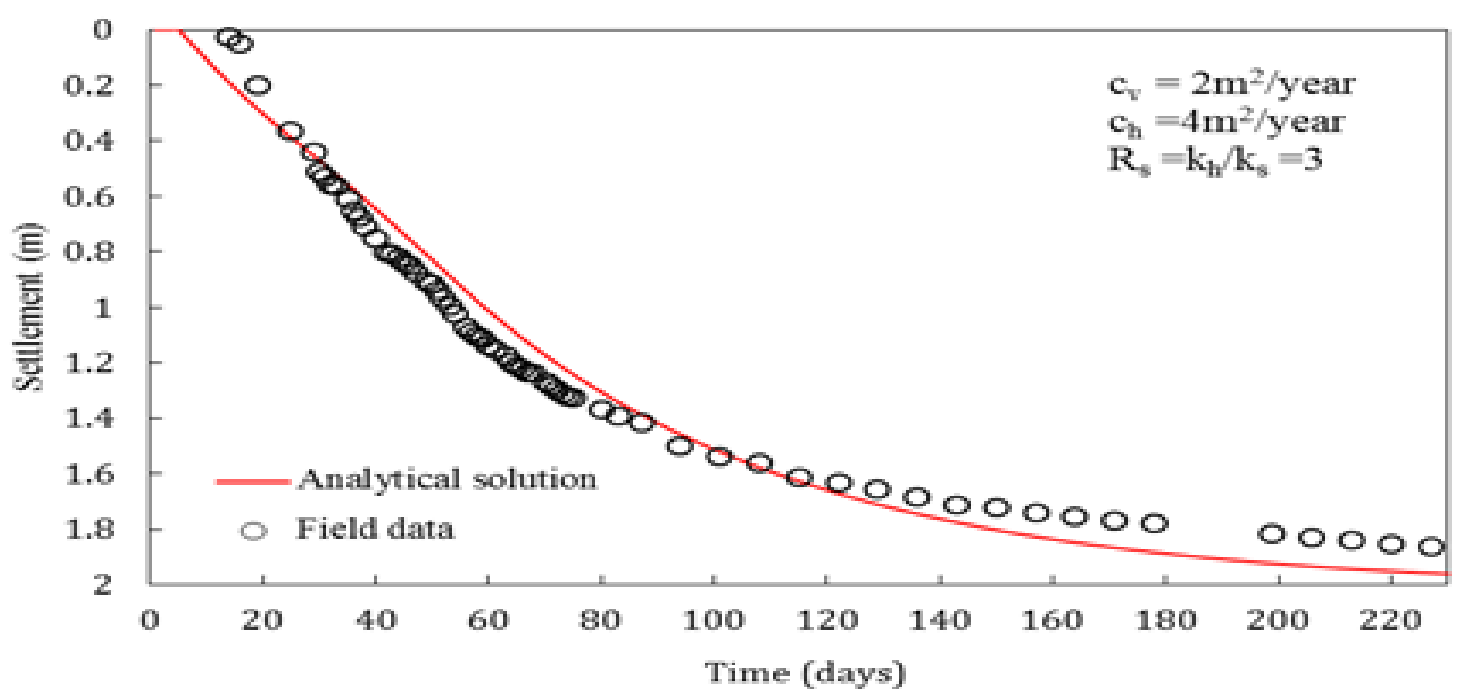

Figure 9. Comparison of surface settlement between the analytical solution and field data

\subsection{Numerical modelling for axisymmetric condition}

ABAQUS numerical software is utilized for modeling the consolidation problem of axisymmetric numerical modeling. The model is shown in Figure 10 with a unit cell section. The total height of the model is $29 \mathrm{~m}$ with 4 soil layers. The length of the PVD is $15 \mathrm{~m}$. The top 
crush and layer 2 were also modeled in this model with a thickness of $1 \mathrm{~m}$ and $3 \mathrm{~m}$, respectively. The vacuum pressure and the surcharge load were applied at the top boundary. Vacuum pressure was assigned as the negative pore-water pressure at a node which could later increase the effective stress and induce the settlement. ABAQUS software is capable of modeling vacuum pressure in cooperating with the advanced soil models such as the modified Cam clay model and Morh-coulomb model. The soft soil model based on the modified Cam clay model is widely applied for PVD consolidation problems of soft soil (Rujikiatkamjor \& Indraratna, 2008, Lin \& Chang, 2009). The soft soil properties for the modified Cam clay model are listed in Table 2. In specific, the in-situ past pressure $\left(p_{c}\right)$ in layer 1a has been approximated by 6 separated layers. It is because the actual past pressures (in Figure 5) are about $10 \mathrm{kPa}-20 \mathrm{kPa}$ larger than the effective pressures, whereas, the past pressure can be only defined as a constant value along with the depth of a layer in the model. Moreover, layer 2 is the silty sand layer which was simplified in the modified Cam clay model with compressive indices of $\kappa=0.011$ and $\lambda=0.11$ and high permeability of $k_{h}=1(\mathrm{~m} /$ day $)$. 


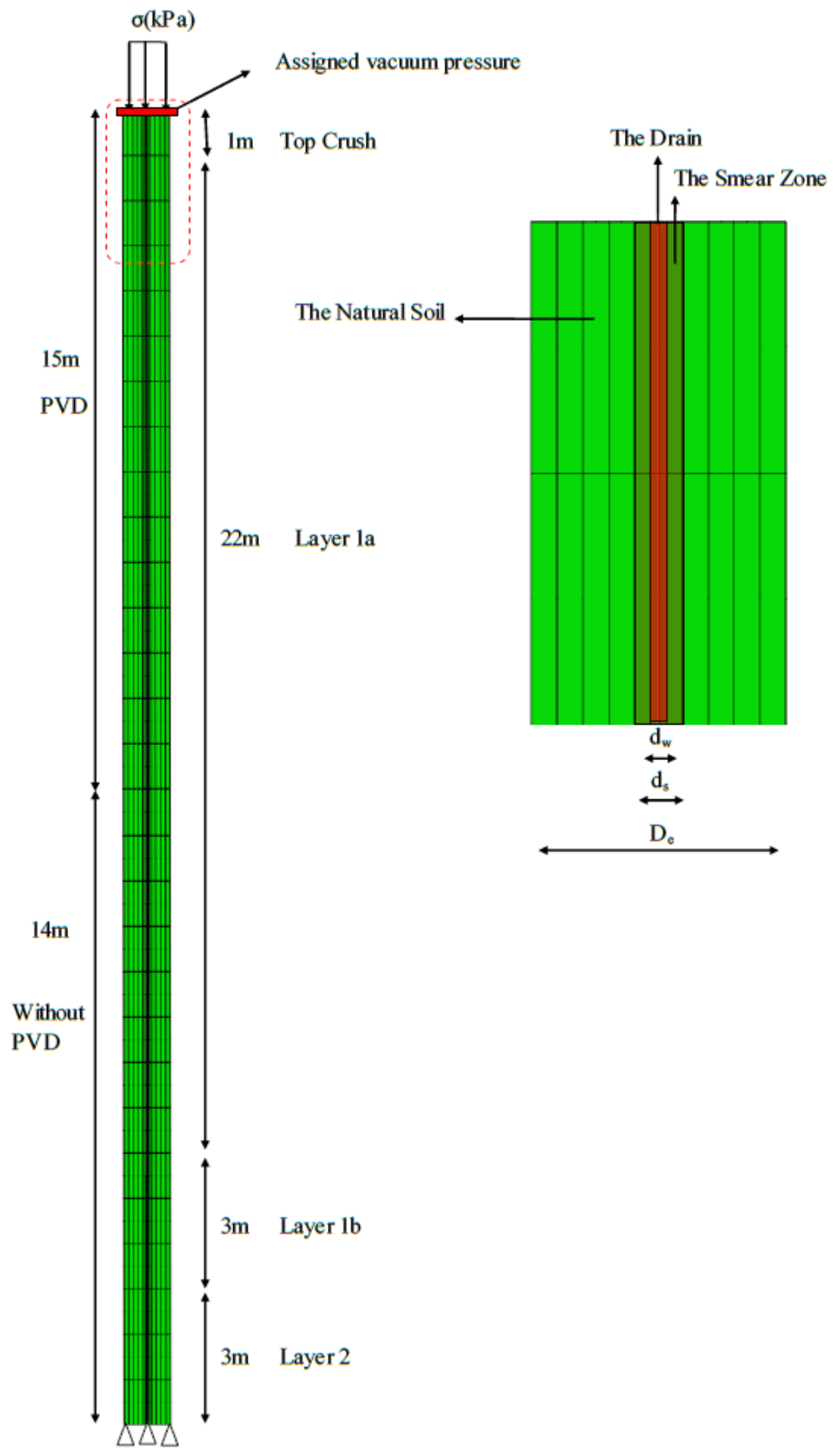

Figure 10. Axisymmetric numerical model 


\section{Table 2}

Soil properties for Modified Camclay model

\begin{tabular}{|c|c|c|c|c|c|c|}
\hline Layer & Depth $(\mathbf{m})$ & $\kappa$ & $\lambda$ & $p_{c}(\mathbf{k P a})$ & $\mathbf{M}$ & $k_{h}$ (m/day) \\
\hline 1a+PVD & $1-3$ & 0.054 & 0.459 & 31.6 & 0.8 & $2 \times 10^{-5}$ \\
\hline 1a+PVD & $3-7$ & 0.054 & 0.459 & 49 & 0.8 & $2 \times 10^{-5}$ \\
\hline 1a+PVD & $7-11$ & 0.054 & 0.459 & 72.7 & 0.8 & $2 \times 10^{-5}$ \\
\hline 1a+PVD & $11-15$ & 0.054 & 0.459 & 95.4 & 0.8 & $2 \times 10^{-5}$ \\
\hline 1a & $15-19$ & 0.054 & 0.459 & 118.6 & 0.8 & $2 \times 10^{-5}$ \\
\hline 1a & $19-23$ & 0.054 & 0.459 & 141.8 & 0.8 & $2 \times 10^{-5}$ \\
\hline 1b & $23-26$ & 0.03 & 0.303 & 156.3 & 1 & $1 \times 10^{-5}$ \\
\hline 2 & $26-29$ & 0.011 & 0.11 & 168.3 & 1 & 1 \\
\hline
\end{tabular}

Source: The researcher's data analysis

Numerical settlement results of the axisymmetric model given in Figure 11 show excellent agreements are not only in the surface settlement but also in all deep settlements. It implies that the numerical and analytical solution could have consistent results if soil/drain properties were appropriately calibrated.

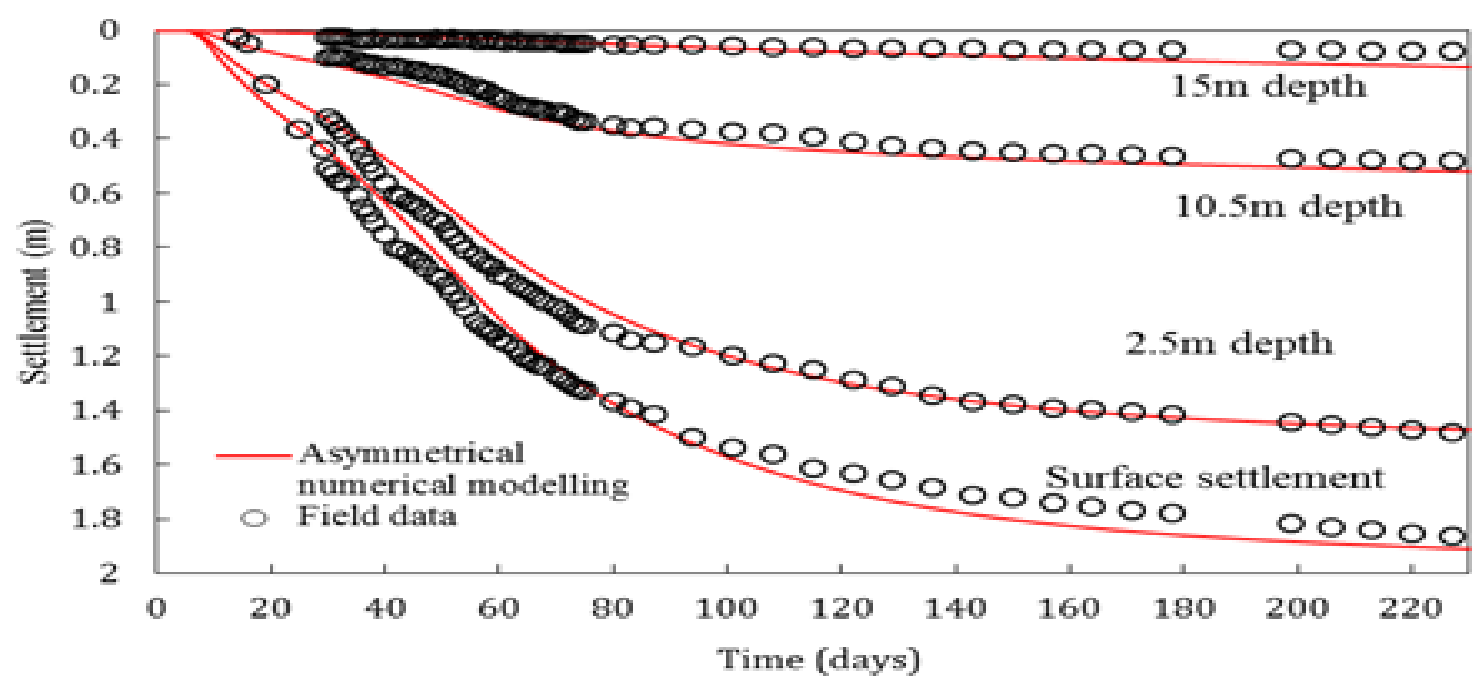

Figure 11. Comparison of settlements by the Asymmetrical numerical modeling and field data

\subsection{Plane strain (2D) numerical modeling}

The soil/drain properties above are utilized for 2D numerical analysis. Meshing is given in Figure 12 with 647 8-node elements of CPE8RP and CPE8R. Soft soil layer 1a with PVD was simplified as a single layer with equivalent vertical permeability (Chai, Shen, Miura, \& Bergado, 2001). The equivalent vertical permeability $k_{e v}$ is an essential factor by Chai's approach is presented in simple equations which considering the PVD's influenced factor $\mu$ and undisturbed vertical, horizontal permeability $\left(k_{v}, k_{h}\right)$ : 


$$
k_{e v}=\left(1+\frac{2.5 l^{2}}{\mu D_{e}^{2}} \frac{k_{h}}{k_{v}}\right) k_{v}
$$

where: $l$ is the drainage length of PVD improved zone, $\mu$ the influence factor of PVD geometry as expressed by Hansbo (1981).

$$
\mu=\ln \left(\frac{n}{s}\right)+\frac{k_{h}}{k_{s}} \ln (s)-\frac{3}{4}+\frac{\pi 2 l^{2} k_{h}}{3 q_{w}}
$$

where: $q_{w}$ is the discharge capacity. This value has been extensively studied as a very large value $q_{w}=100 \mathrm{~m}^{3} /$ year, while the horizontal permeability is a very small value. Therefore the last term in equation (2) can be neglected. $n=\frac{D_{e}}{d_{w}}$, and $s=\frac{d_{s}}{d_{w}}$.

Nevertheless, the ratio of permeability $R_{s}=\frac{k_{h}}{k_{s}}=3$ used to derive the equivalent vertical permeability leads to faster-predicted settlement than field data measurements. Therefore, it is proposed a higher ratio of permeability of $R_{s}=\frac{k_{h}}{k_{s}}=8$ corresponding $k_{e v}=1.62 \times 10^{-3}(\mathrm{~m} /$ day $)$. As a result, the settlement results of the $2 \mathrm{D}$ numerical analysis are matched with the field data as shown in Figure 13. The ratio of permeability $R_{s}=\frac{k_{h}}{k_{s}}=8$ was also proposed by Lam et al. (2015) when modeling vacuum consolidation of PVD in the second international Bangkok airport.

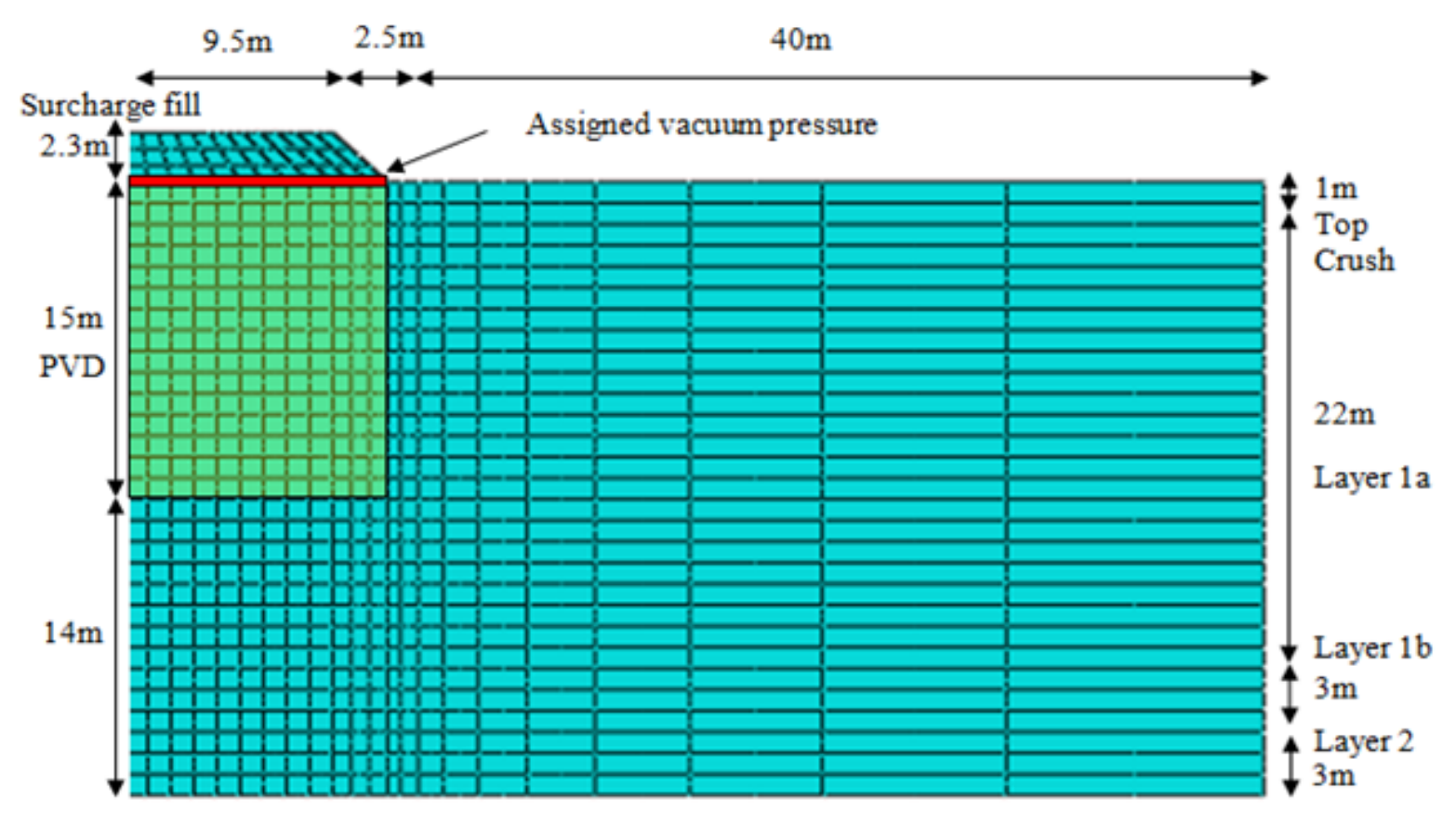

Figure 12. 2D plane strain numerical model 


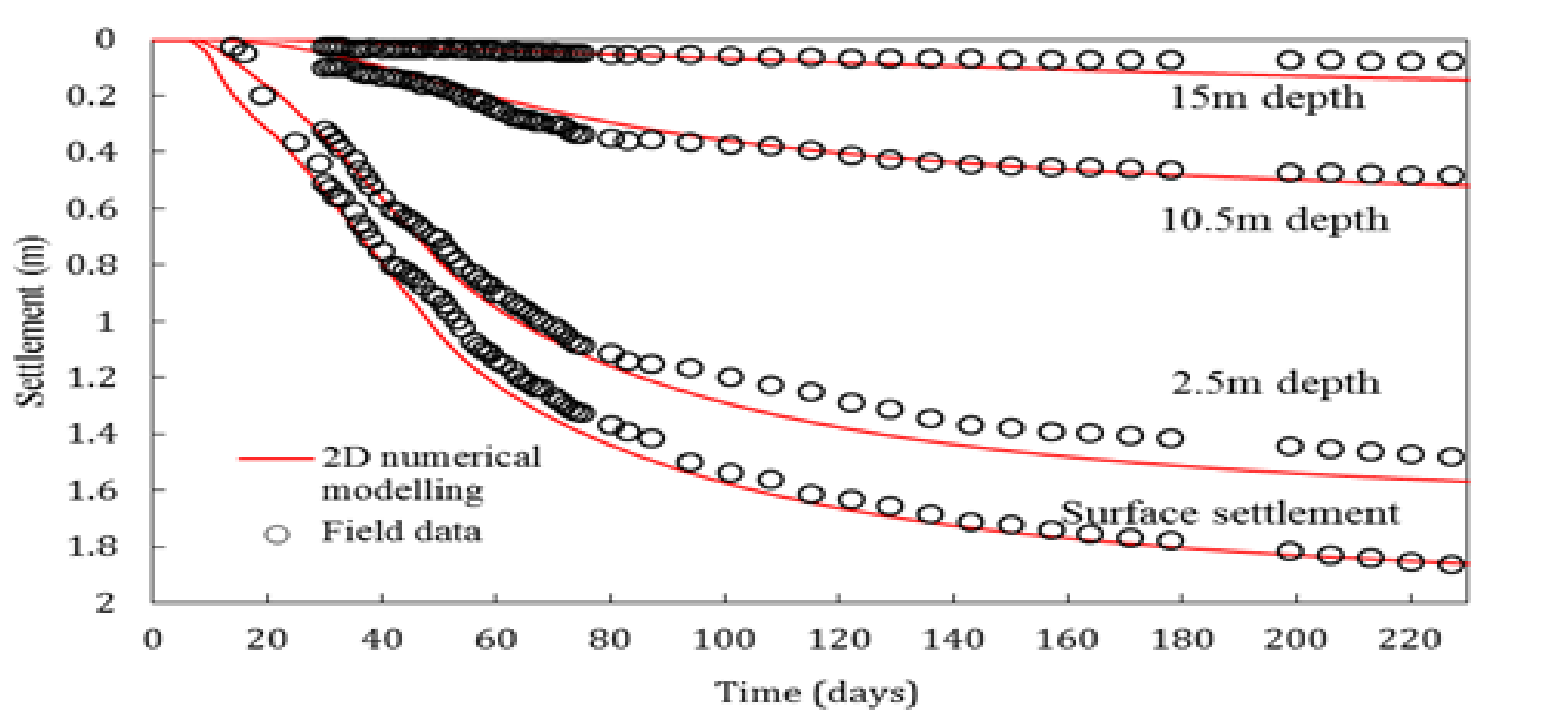

Figure 13. Comparison of settlements by the $2 \mathrm{D}$ numerical modeling and field data

\subsection{Influence zone}

The influence zone can be determined by means of soil deformation during the treatment. As shown in Figure 14, the maximum lateral displacement is $0.5 \mathrm{~m}$ inward the embankment due to the vacuum force. This movement significantly decreased to $0.1 \mathrm{~m}$ at $7.5 \mathrm{~m}$ away from the slope toe; and it was negligible at $10 \mathrm{~m}$ away from the embankment's toe. Thus, it can be concluded that in this soil treatment the safe boundary may extend to the length of at least $10 \mathrm{~m}$ from the embankment's toe. Moreover, an existing structure may be severely damaged if it locates within $7.5 \mathrm{~m}$ from the surcharge toe. 


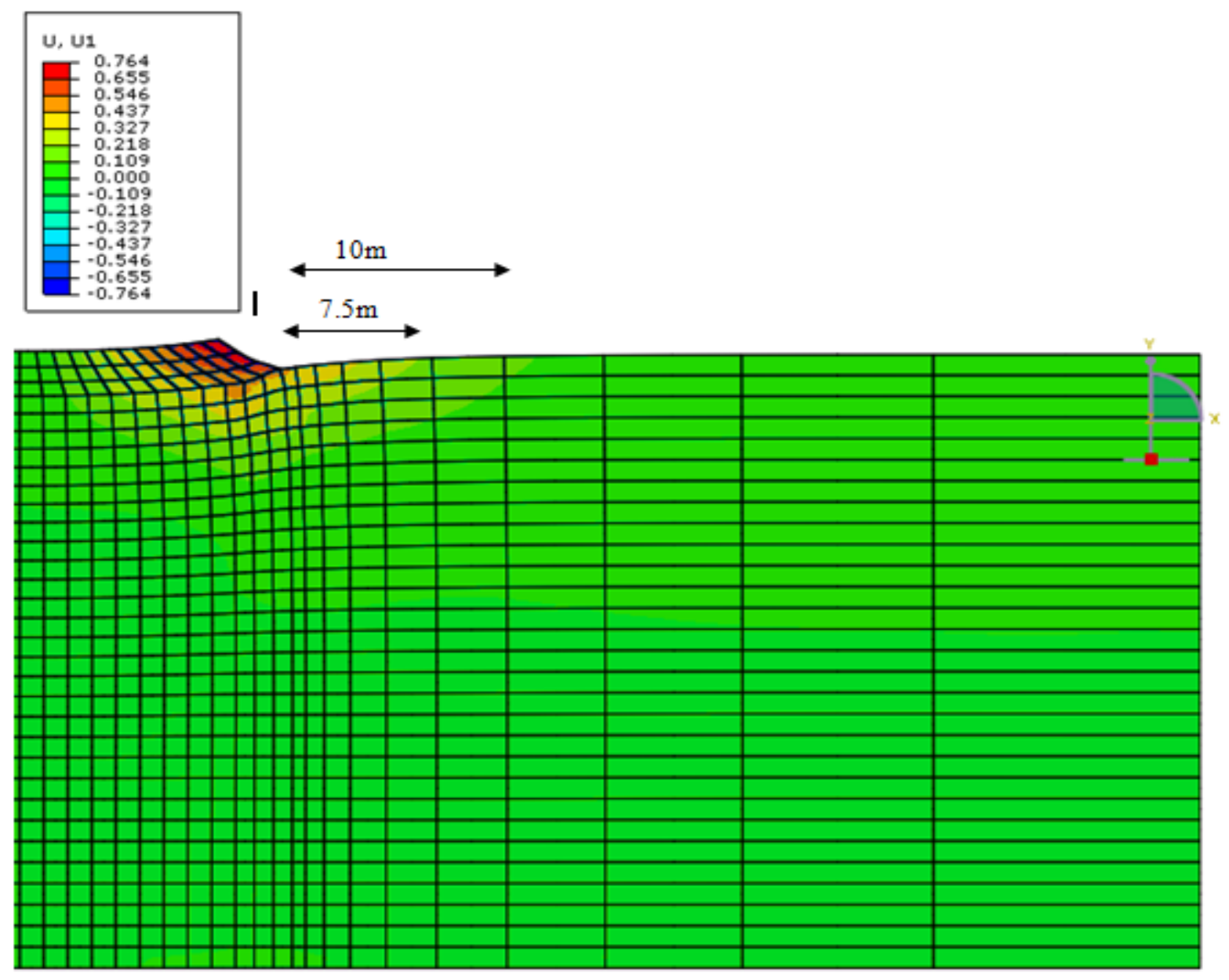

Figure 14. Lateral displacement by 2D numerical modeling

\subsection{Evaluating degree of consolidation of non-PVD zone}

The most challenging task is the evaluation of the untreated zone because it can have a very low dissipation of the excess pore pressures and it may cause large settlement. By means of numerical modeling, this paper presents two simple approaches including (1) evaluation through the excess pore water pressures dissipation and (2) evaluation through the effective vertical pressure changes.

\section{A-The first approach}

Pore pressure in the axisymmetric model given in Figure 15 shows that excess pore pressure of $26 \mathrm{kPa}$ still remains in the untreated zone while the treated zone is completely consolidated with the excess pore pressure of $-60 \mathrm{kPa}$ (equal to the vacuum pressure). The total magnitude of excess pore water pressure of $100 \mathrm{kPa}$ is the summation of the maximum surcharge load $(40 \mathrm{kPa})$ and the maximum vacuum pressure $(-60 \mathrm{kPa})$. Therefore, the degree of consolidation at the final consolidation stage ( 240 days) is calculated by the following equation:

$$
U_{\text {Asym }}=\frac{u_{\text {surcharge }}-u_{t}}{u_{\text {total }}}=\frac{40-26}{100} 100 \%=14 \%
$$


where: $U_{\text {Asym }}$ is the degree of consolidation by the axisymmetric model, $u_{\text {surcharge }}$ is the maximum excess pore pressure induced by maximum surcharge loading, $u_{\text {total }}$ is the total of excess pore pressure, $u_{t}$ is the excess pore pressure at the final consolidation stage (240 days).

The excess pore pressure at the final consolidation stage in the $2 \mathrm{D}$ model is shown in Figure 16 . The excess pore pressure of the untreated zone only $6.849 \mathrm{kPa}$ which is lower than that of the axisymmetric model. The reason may come from the difference in the surcharge stress distribution in the 2D model and in the axisymmetric model. Figure 17 presents the vertical stress distribution due to an embankment by the analytical solution. It can be seen from Figure 17 that the vertical stress reduces when the depth increases under an embankment. The middle of the untreated zone has a depth of $22 \mathrm{~m}$. The influence value at this depth is $I=0.25$

The maximum stress distribution at that depth is

$$
\Delta \sigma_{z}=2 I \sigma=2 \times 0.25 \times 40=20(\mathrm{kPa})
$$

The maximum stress in the middle of the untreated zone is also the maximum excess pore pressure by surcharge loading.

$$
u_{\text {surcharge }}=\Delta \sigma_{z}=20(\mathrm{kPa})
$$

The total excess pore pressure is the summation of the vacuum pressure and the excess pore pressure by the surcharge loading.

$$
u_{\text {total }}=u_{v a}+u_{\text {surcharge }}=|-60|+20=80(\mathrm{kPa})
$$
equation:

The degree of consolidation at the final consolidation stage is determined by the

$$
U_{2 D}=\frac{u_{\text {surcharge }}-u_{t}}{u_{\text {total }}}=\frac{20-6.8}{80} 100 \%=16.5 \%
$$

where $U_{2 D}$ is the degree of consolidation by the $2 \mathrm{D}$ model.

The degree of consolidations by both numerical models are in good agreement. The untreated zone had a little increase in the degree of consolidation (14\%-16.5\%). 


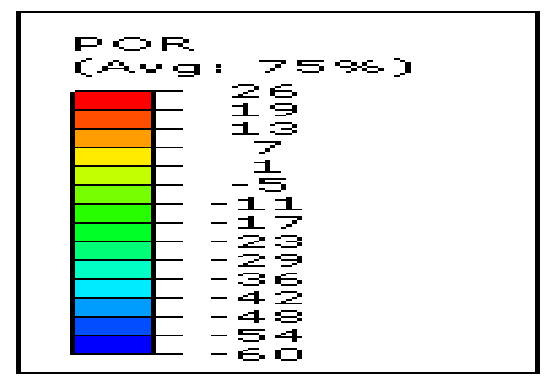

Figure 15. Excess pore pressure at the final consolidation stage by axisymmetric modelling 

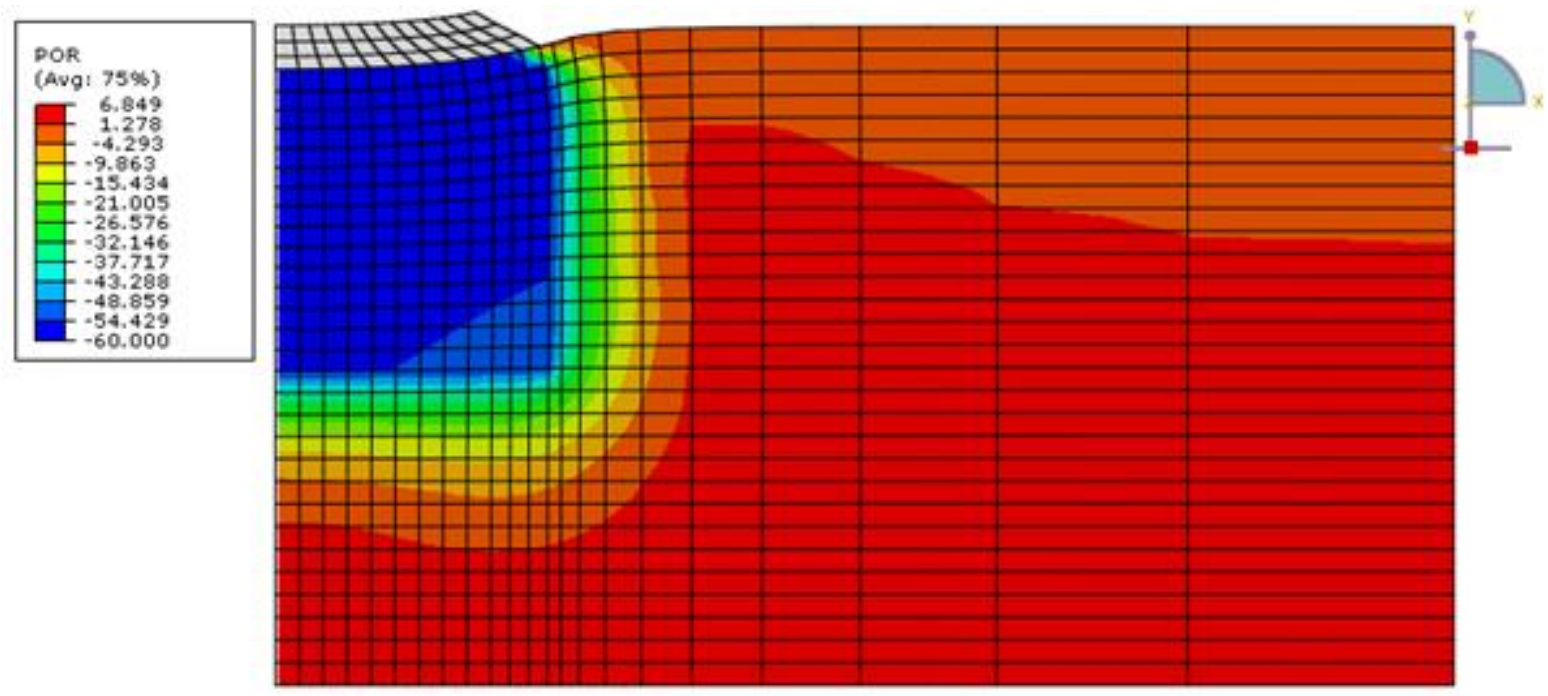

Figure 16. Excess pore pressure at the final consolidation stage by $2 \mathrm{D}$ modelling

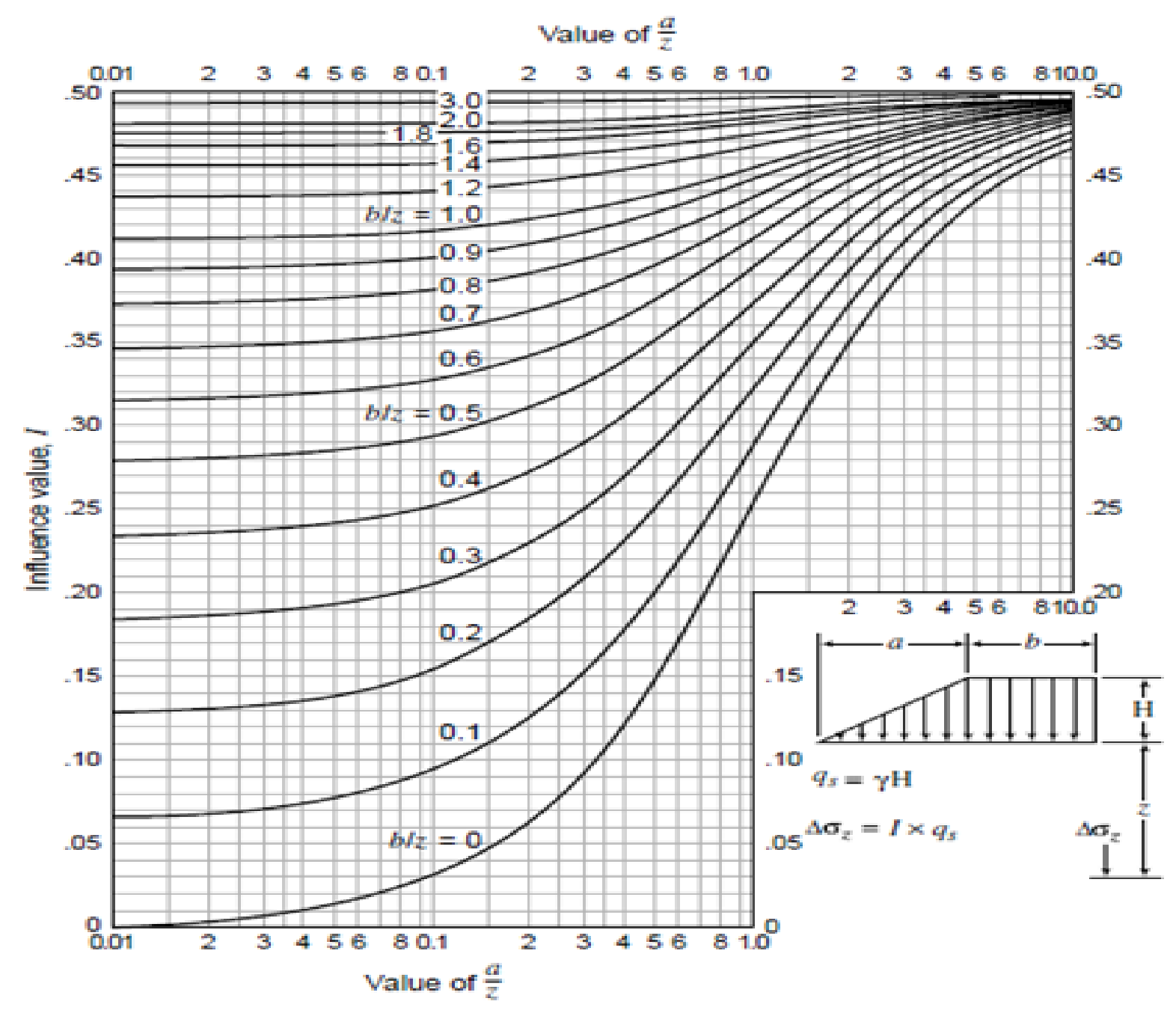

Figure 17. Stress distribution under an embankment load 


\section{B-The second approach}

The effective vertical pressure at the initial stress state is illustrated in Figure 18. The vertical stress linearly increases along with the depth due to the self-weight of soil to the maximum value of $-168.2(\mathrm{kPa})$. While Figure 19 shows the stress increase at the final consolidation stage. The untreated zone shows not much increase in terms of the effective vertical pressure while the treated zone shows significant improvement (the tresses change at least $70 \mathrm{kPa})$.

The stress level in the middle of the untreated zone is about -112 to $-126(\mathrm{kPa})$ at the initial state, while they are about -125 to $140(\mathrm{kPa})$ at the final consolidation stage (240 days) (Figure 18 and Figure 19). The average vertical effective stress increase is $\Delta \sigma^{\prime}{ }_{t}=13.5(\mathrm{kPa})$, while the total vertical effective stress increase (when the excess pore pressure is completely dissipated at the middle of the untreated zone) is $\sigma_{\text {total }}^{\prime}=u_{\text {total }}=80(\mathrm{kPa})$. Therefore, the degree of consolidation is determined by the equation:

$$
U=\frac{\Delta \sigma_{t}^{\prime}}{\sigma_{\text {total }}^{\prime}}=\frac{13.5}{80} 100 \%=16.8 \%
$$

The degrees of consolidation by the first and second approaches are almost matched (16.5 and $16.8 \%$, respectively) indicating that the untreated zone has very low improvement with the average stress increase of $13.5 \mathrm{kPa}$.

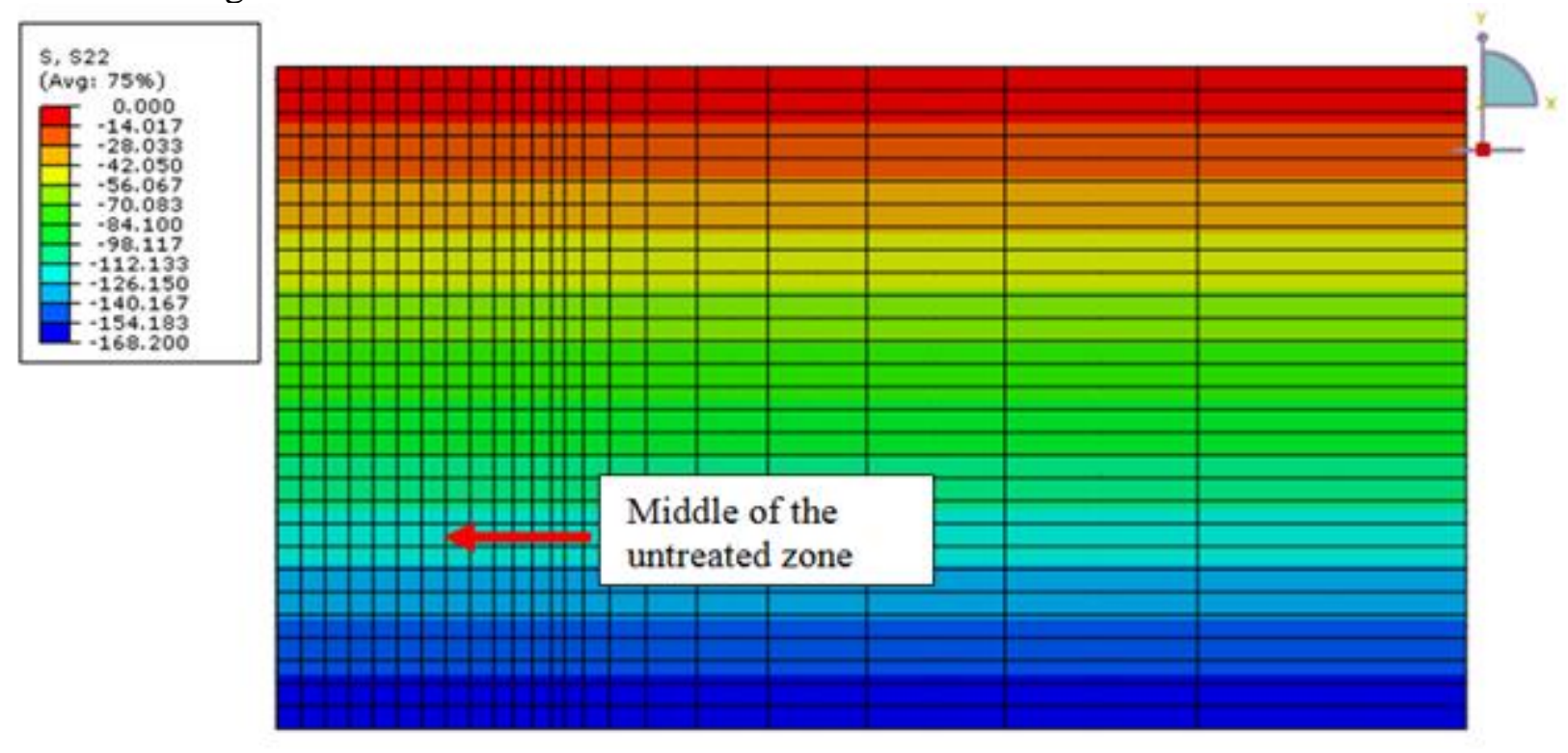

Figure 18. The initial state of vertical effective stress 


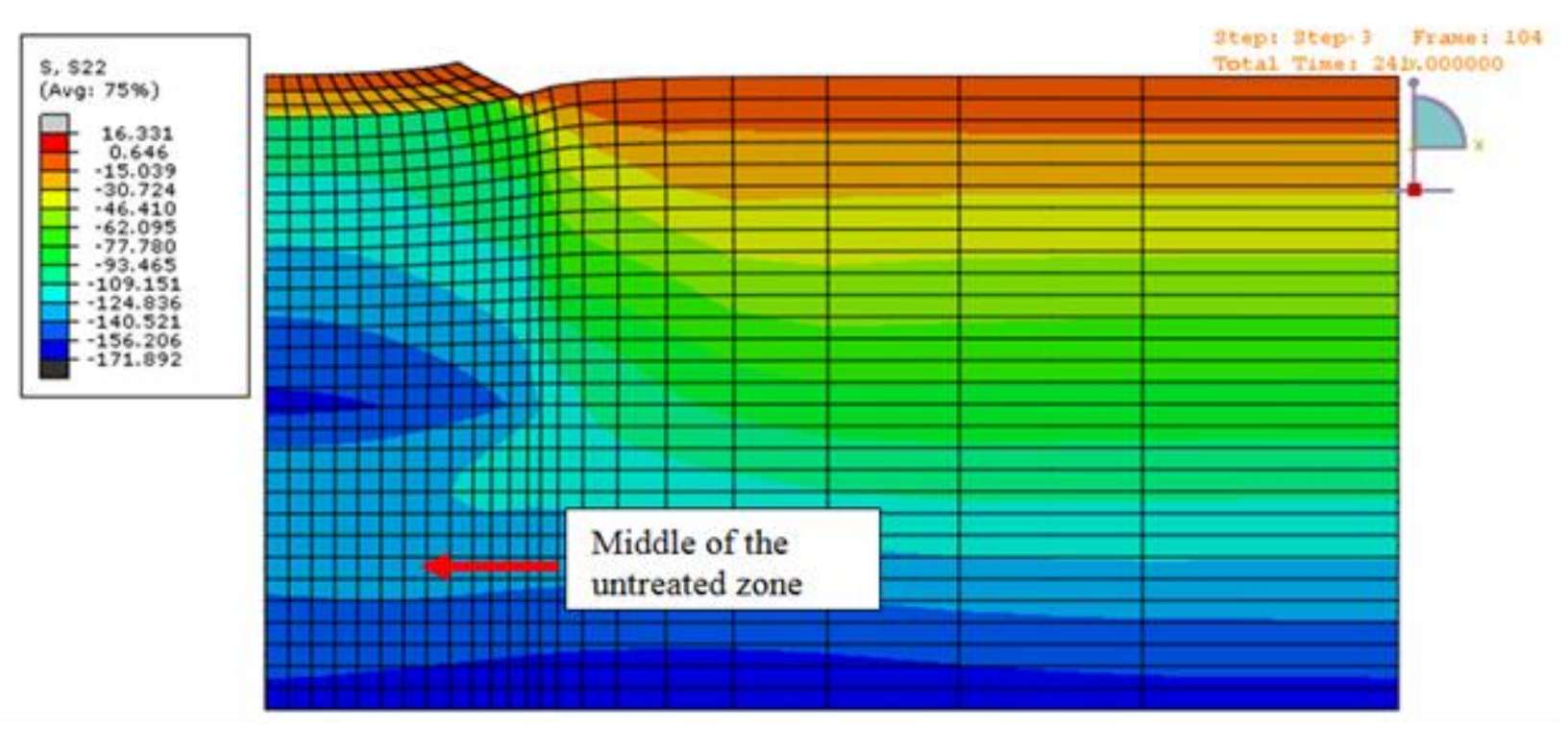

Figure 19. the vertical effective stress at the final consolidation stage

\subsection{Field verification}

Field tests by static cone penetrated test $(\mathrm{CPTu})$ carried out before and after treatment were shown in Figure 20. The treated zone shows great improvement in terms of the net cone resistance $(0.65 \mathrm{MPa})$. with almost double the initial value $(0.35 \mathrm{MPa})$ while, the untreated zone has a little increase in cone resistance. That can be explained by the shear strength increase by the SHANSEP technique (Ladd, Foott, Ishihara, Schlosser, \& Poulos, 1977).

$$
\left(\frac{c_{u}}{\sigma_{v}}\right)_{O C}=\left(\frac{c_{u}}{\sigma_{v}}\right)_{N C} O C R^{m}
$$

where $\left(\frac{c_{u}}{\sigma_{v}}\right)_{N C}=0.25$ silty clay, $m=0.8, O C R=1.2$ is the over-consolidation ratio of the middle of the untreated zone.

Substituting the above values to equation (9) yields

$$
\left(\frac{c_{u}}{\sigma_{v}}\right)=0.25 \times 1.2^{0.8}=0.29
$$

Substituting the vertical effective stress increase $\Delta \sigma^{\prime}{ }_{v}$ the equation (10) can be rewritten in the form of shear strength increase $\Delta c_{u}$.

$$
\left(\frac{\Delta c_{u}}{\Delta \sigma_{v}}\right)=0.29
$$

Based on the plane strain analysis, the average vertical effective stress increase by the numerical method of $\Delta \sigma^{\prime}{ }_{v}=13.5(\mathrm{kPa})$, subsequently the increase in shear strength is: 


$$
\Delta c_{u}=0.29 \times 13.5=3.9(\mathrm{kPa}) .
$$

The shear strength increase was very low $\left(\Delta c_{u}=3.9 \mathrm{kPa}\right)$ therefore, it can not make changes in the net cone resistance of CPT tests. The results of field tests and numerical modelings proved the untreated zone could hardly be improved by consolidation technique.

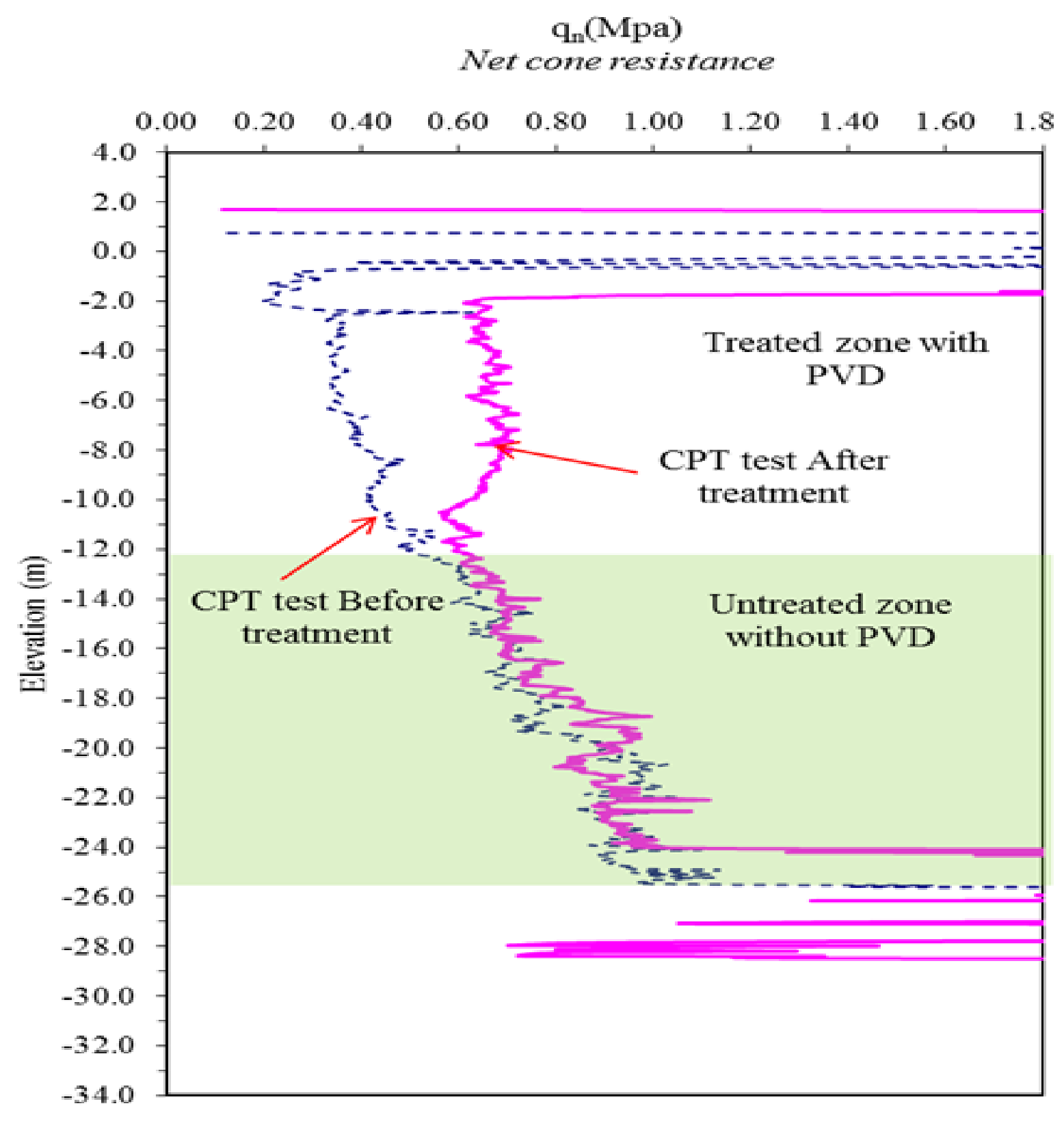

Figure 20. CPTu tests before and after treatment

\subsection{Evaluation of residual settlement}

The residual settlement is the serviceability settlement when the road is under vehicle loading. The low degree of consolidation of the non-PVD layer may cause residual settlements if increased stresses by operational loading are larger than the past pressures by surcharge 
loading. The residual settlements are evaluated by numerical modeling with the whole process of load removal and operation load. The load removal is the vacuum pressure of $-60 \mathrm{kPa}$ and the operation load is the vehicle load of $15 \mathrm{kPa}$. The total time of residual settlement is 10 years after completing construction. The loading sequences are given in Figure 21.

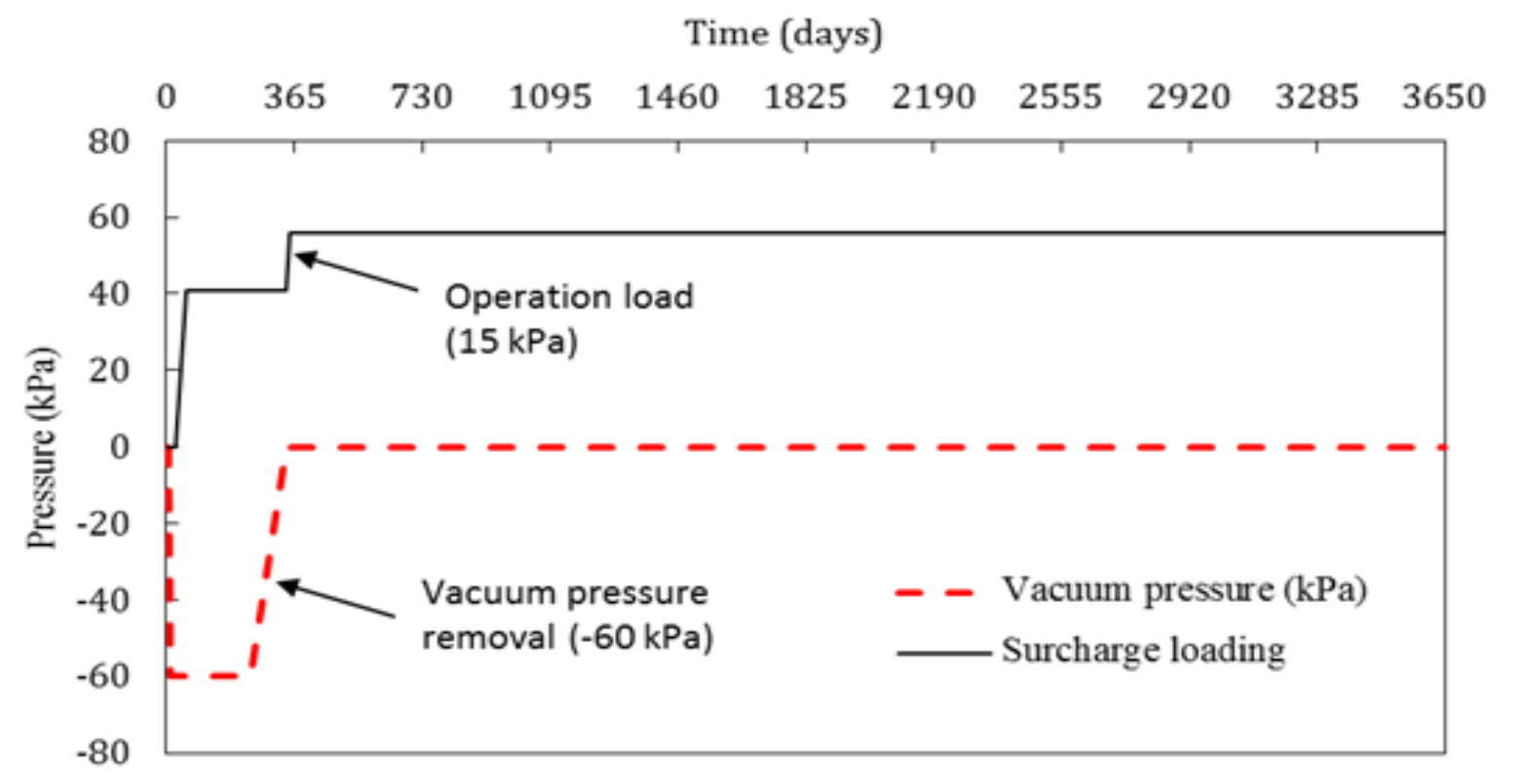

Figure 21. Loading sequences of load removal and operation load

The estimated residual settlement is shown in Figure 22 in which no further settlement is observed. It can be attributed to (a) operation surcharge $(15 \mathrm{kPa})$ is significantly smaller than the vacuum load $(-60 \mathrm{kPa})$ and (b) stress increase of $7.5 \mathrm{kPa}$ due to the operation load is lower than the past stress increase of $13.5 \mathrm{kPa}$ during the ground treatment. Thus, the residual settlement is the only secondary settlement.

Moreover, the settlement due to the creep effect can be estimated analytically by

$$
S_{s}=C_{\alpha} \cdot H \cdot \log \frac{t_{p}}{t_{o}}
$$

where the second coefficient $C_{\alpha}=1.1 \times 10^{-2}$ is determined through odometer tests, $H=24(\mathrm{~m})$ is the total thickness of the compressive layer, $t_{p}=15$ (years) is the design time, $t_{o}=1$ (year) is the completed consolidation time. Therefore, the residual settlement can be calculated as

$$
S_{s}=C_{\alpha} \cdot H \cdot \log \frac{t_{p}}{t_{o}}=1.1 \times 10^{-2} \times 24 \times \log \frac{15}{1}=0.3(\mathrm{~m})
$$

These residual settlements for 15 years are satisfactory required residual settlement of $0.4 \mathrm{~m}$ for 15 years according to Vietnam's road standard. 


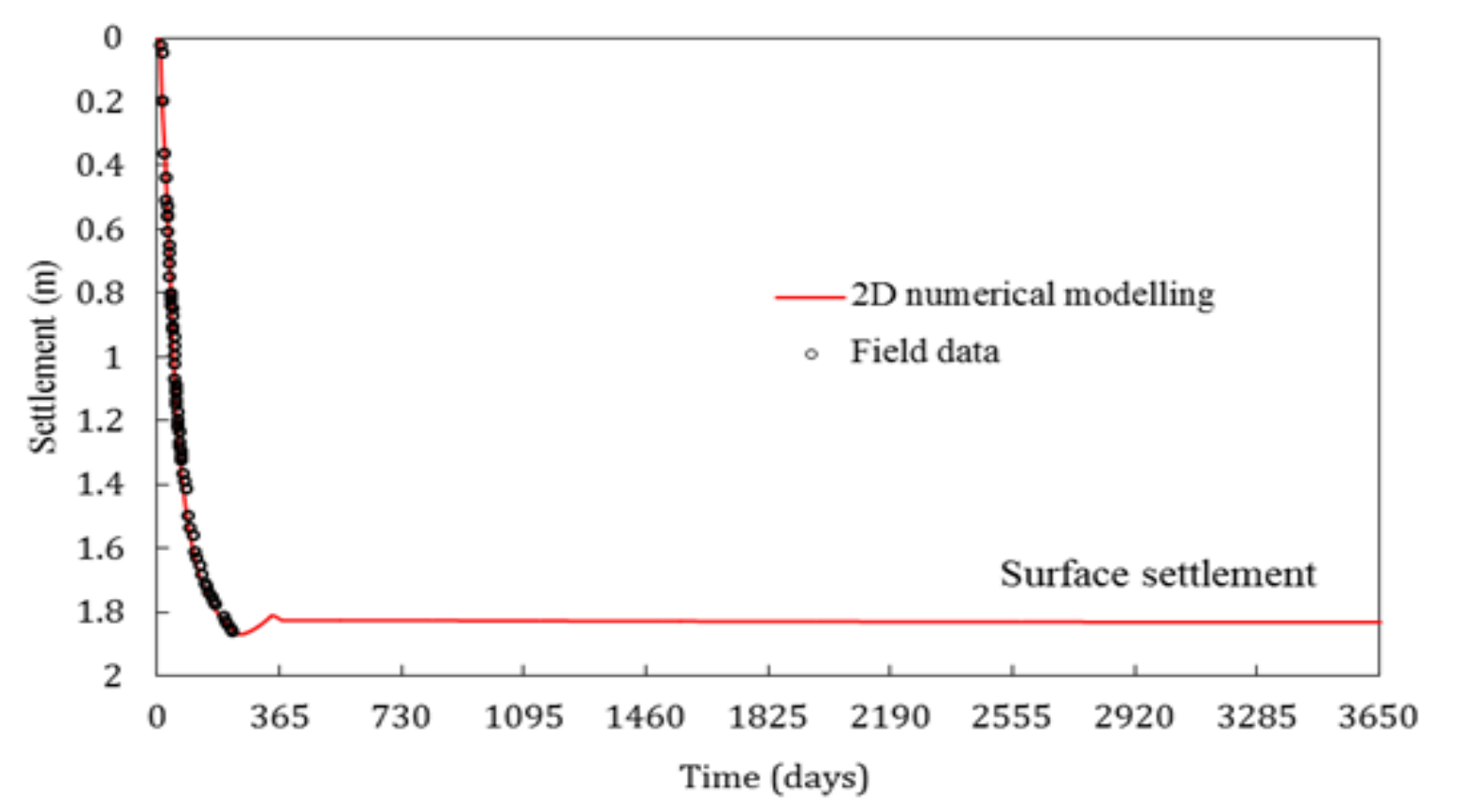

Figure 22. Residual settlement

\section{Conclusions and recommendations}

Several conclusions can be drawn from the Bachiem road project:

1- This paper introduces a matching scheme for selecting the soil/drain properties for numerical modeling. There are excellent consistent in soil/drain properties of the analytical solution and the axisymmetric modeling, while the 2D modeling has to adjust the equivalent vertical drain with direct relation to the permeability ratio of $R_{s}=\frac{k_{h}}{k_{s}}$;

2- The analytical solution and the axisymmetric modeling have the permeability ratio of $R_{s}=\frac{k_{h}}{k_{s}}=3$, while the 2D modeling has the permeability ratio of $R_{s}=\frac{k_{h}}{k_{s}}=8$. The analysis results in terms of settlement of these models are in good agreement with the field data;

3 - The lateral displacement of the vacuum consolidation technique investigated by $2 \mathrm{D}$ modeling indicated that the safe boundary for existing constructions would be $10 \mathrm{~m}$ from the embankment's toe. The effectiveness of soil treatment can be verified by the CPTu test. The cone resistance increased significantly within the PVD boundary, meanwhile;

4- Numerical results of the untreated zone are then verified by the cone penetrated tests. The field test results are consistent with numerical results which prove the effectiveness of the numerical methods in solving the complicated consolidation problems by PVD vacuum technique;

5- Load removal of vacuum pressure and the operation load of vehicle loading can be modeled by numerical simulation to investigate the residual settlement. However, it needs a more advanced model that is capable of simulation of the creep effect. The residual settlement of the analysis section is satisfied with the required settlement by relevant Vietnam's standard. 


\section{References}

Artidteang, S., Bergado, D. T., Saowapakpiboon, J., Teerachaikulpanich, N., \& Kumar, A., (2011). Enhancement of efficiency of prefabricated vertical drains using surcharge, vacuum and heat preloading. Geosynthetics International, 18(1), 35-47.

Asaoka, A. (1978). Observational procedure of settlement prediction. Soils Found, 18(4), 87101.

Balasubramaniam, A. S., Bergado, D. T., \& Phienwej, N. (1995). The full scale field test of prefabricated vertical drains for the Second Bangkok International Airport (SBIA). Paper presented at Division of Geotechnical and Transportation Engineering, AIT, Bangkok, Thailand.

Barron, R. A. (1948). Consolidation of fine-grained soils by drain wells. Transactions ASCE, 113, Paper 2346, 718-724.

Bergado, D. T., Balasubramaniam, A. S., Fannin, R. J., \& Holtz, R. D. (2002). Prefabricated vertical drains (PVDs) in soft Bangkok clay: A case study of the new Bangkok International Airport Project. Canadian Geotechnical Journal, 39(2), 304-315.

Bergado, D. T., Chai, J. C., Miura, N., \& Balasubramaniam, A. S. (1998). PVD improvement of soft Bangkok clay with combined vacuum and reduced sandembankment preloading. Geotechnical Engineering Journal Southeast Asian Geotechnical Society, 29(1), 95-121.

Bergado, D. T., Long, P. V., \& Balasubramaniam, A. S. (1996). Compressibility and flow parameters from PVD improved soft Bangkok clay. Geotechnical Engineering Journal. $27(1), 1-20$.

Chai, J. C., Carter, J. P., \& Bergado, D. T. (2013b). Behaviour of clay subjecting to vacuum and surcharge loading in an odometer. Geotechnical Engineering Journal SEAGS AGSSEA, 44(4), 1-8.

Chai, J. C., Miura, N., \& Bergado, D. T. (2008). Preloading clayey deposit by vacuum pressure with cap-drain: Analyses versus performance. Geotextile Geomembrane Journal, 26(3), 220-230.

Chai, J. C., Ong, C. Y., Carter, J. P., \& Bergado, D. T. (2013a). Lateral displacement under combined vacuum pressure and embankment loading. Geotechnique, 63(10), 842-856.

Chai, J.-C., Shen, S.-L., Miura, N., \& Bergado, D. T. (2001). Simplified method of modeling PVD-improved subsoil. Geotechnique, 127(11), 965-972.

Chu, J., Yan, S. W., \& Yang, H. (2000). Soil improvement by the vacuum preloading method for an oil storage station. Geotechnique, 50(6), 625-632.

Geng, X. Y., Indraratna, B., \& Rujikiatkamjorn, C. (2012). Analytical solutions for a single vertical drain with vacuum and time-dependent surcharge preloading in membrane and membraneless system. International Journal of Geomechanics ASCE, 12(1), 27-42.

Han, J. (2015). Priciples and practice of ground improvement. New Zealand: Wily Publishing Company. 
Hansbo, S. (1981). Consolidation of fine-grained soils by prefabricated drains. Proceedings of the 10th International Conference on Soil Mechanics and Foundation Engineering: Stockholm, 3, 677-682.

Hausmann, M. R. (1990). Engineering principal of ground modification. New York, NY: McGraw-Hill Publishing Company.

Indraratna, B., Rujikiatkamjorn, C., \& Sathananthan, I. (2005). Analytical and numerical solutions for a single vertical drain including the effects of vacuum preloading. Canadian Geotechnical Journal, 42, 994-1014.

Indraratna, B., Rujikiatkamjorn, C., Ameratunga, J., \& Boyle, P. (2011). Performance and prediction of vacuum combined with surcharge consolidation at Port of Brisbane. Journal of Geotechnical \& Geoenvironmental Engineering ASCE, 137(1), 1009-1018.

Indraratna, B., Rujikiatkamjorn, C., Balasubramaniam, A. S., \& McIntosh, G. (2012). Soft ground improvement via vertical drains and vacuum assisted preloading. Geotextile Geomembrane Journal, 30(1), 16-23.

Jamiolkowski, M., Lancellotta, R., \& Wolski, W. (1983). Precompression and speeding up consolidation. Proceedings 8th ECSMFE, 1201-1206.

Kelly, R. B., \& Wong, P. K. (2009). An embankment constructed using vacuum consolidation. Australian Geomechanics Journal, 44(2), 55-64.

Ladd, C. C., Foott, R., Ishihara, K., Schlosser, F., \& Poulos, H. G. (1977). Stress deformation and strength characteristics. Proceedings 9th ICSMFE. Tokyo, 2, 421-494.

Ladd, C. C., \& DeGroot, D. J. (2003). Recommended practice for soft ground site characterization: Arthur casagrande lecture. Paper presented at the 12th Panamerican Conference on Soil Mechanics and Geotechnical Engineering, MIT, Cambridge, MA.

Lam, L. G., Bergado, D. T., \& Hino, T. (2015). PVD improvement of soft Bangkok clay with and without vacuum preloading using analytical and numerical analyses. Geotextile Geomembrane Journal, 43(6), 547-557.

Lin, D. G., \& Chang, K. T. (2009). Three-dimensional numerical modeling of soft ground improved by prefabricated vertical drains. Geosymthetics International, 16(5), 339-353.

Long, P. V. (2005). Existing problems of Vietnamese design standards for highway embankment on soft ground. Proceeding of the 13th conference on Road and Brigde sections, Politechnical University Ho Chi Minh City, 1, 733-738.

Long, P. V., Bergado, D. T., Giao, P. H., Balasubramaniam, A. S., \& Quang, N. C. (2006). Back analyses of compressibility and flow parameters of PVD improved soft ground in Southern Vietnam. Proceeding of the 8th International Conference on Geosynthetics, Yokohama 2006, 2, 465-468.

Long, P. V., Bergado, D. T., Nguyen, L. V., \& Balasubramaniam, A. S. (2013). Design and performance of soft ground improvement using PVD with and without vacuum consolidation. Geotechnical Engineering Journal SEAGS AGSSEA, 44(4), 37-52.

Long, P. V., Nguyen, L. V., Tri, T. D., \& Balasubramaniam, A. S. (2016). Performance and analyses of thick soft clay deposit improved by PVD with surcharge preloading and 
vacuum consolidation - A case study at CMIT. Geotechnical Engineering Journal SEAGS AGSSEA, 19(4), 125-134.

Mesri, G., Strak, T. D., Ajlouni, M. A., \& Chen, C. S. (1997). Secondary compression of peat with or without surcharging. International Journal of Geomechanics ASCE, 124(5), 411421.

Ong, C. Y., \& Chai, J. C. (2011). Lateral displacement of soft ground under vacuum pressure and surcharge load. Frontiers of Architecture and Civil Engineering in China, 5(2), 239248.

Rixner, J. J., Kraemer, S. R., \& Smith, A. D. (1986). Prefabricated Vertical Drains (Vols. I, II and III) - Summary of research report: Final report (Report No. FHWA-RD-86/169). Washington, D.C.: Federal Highway Administration.

Rujikiatkamjorn, C., \& Indraratna, B. (2007). Soft ground improvement by vacuum assisted preloading. Australian Geomechanics Journal, 42, 19-30.

Rujikiatkamjorn, C., \& Indraratna, B. (2008). 2D and 3D numerical modelling of combined surcharge and vacuum preloading with vertical drains. Geomechanics Journal, 8(2), 144156.

Rujikiatkamjorn, C., \& Indraratna, B. (2009). Design procedure for vertical drains considering a linear variation of lateral permeability within the smear zone. Canadian Geotechnical Journal, 46(3), 270-280.

Rujikiatkamjorn, C., \& Indraratna, B. (2013). Current state of the art in vacuum preloading for stabilizing soft soil. Geotechnical Engineering Journal, 44(4), 77-87.

Voottipruex, P., Bergado, D. T., Lam, L. G., \& Hino, T. (2014). Back-analysis of low parameters of PVD improved soft Bangkok clay with and without vacuum preloading from settlement data and numerical simulations. Geotextile Geomembrane Journal, 42(5), 457-467.

Yan, S. W., \& Chu, J. (2005). Soil improvement for a storage yard using the combined vacuum and fill preloading method. Canadian Geotechnical Journal, 42(4), 1094-1104. 